\begin{tabular}{|c|c|c|}
\hline & KEMAS 16 (2) (2020) 200-206 & OREMAS \\
\hline & Jurnal Kesehatan Masyarakat & 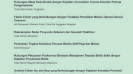 \\
\hline & http://journal.unnes.ac.id/nju/index.php/kemas & $=-m=$ \\
\hline
\end{tabular}

\title{
Nutrition Status and Occupancy Density Compliance with Home Contact Pulmonary TB Insidence in Specialized Hospital of Pulmonary
}

\author{
Dahwan $^{\bowtie}$, Fazidah Aguslina, Wirsal Hasan \\ S2 Public Health Sciences, Faculty of Public Health, University of North Sumatra
}

\begin{tabular}{l} 
Article Info \\
\hline Article History: \\
Submitted December 2019 \\
Accepted April 2020 \\
Published November 2020 \\
\hline Keywords: \\
Nutritional status, dwelling \\
density, lung tuberculosis \\
\hline DOI \\
https://doi.org/10.15294/ \\
kemas.v16i2.22601
\end{tabular}

\begin{abstract}
Pulmonary Tuberculosis is an important and serious public health problem throughout the world. It is caused by Mycobacterium tuberculosis which attacks lungs and other body organs. This study aimed to determine the effects of nutritional status and dwelling density on the risk of pulmonary TB incidence in Medan, North Sumatera. This was a case control study conducted at Pulmonary Disease Hospital, Medan, North Sumatera, from January to June in 2018. A sample of 120 patients was selected for this study, consisting 60 patients with TB and 60 patients without TB. The dependent variable was TB incidence. Data were collected through observations and interviews using questionnaires. Data was analyzed by bivariate using simple logistic regression test and multivariate by multiple logistic regression. The result showed poor nutritional status is closely associated with pulmonary TB infection. Impact of nutritional status and occupancy density on incidence of Pulmonary contact TB at Median Specialized Hospital in 2018.
\end{abstract}

\section{Introduction}

Tuberculosis is an infectious disease that is very dangerous and can cause death. This disease is caused by the bacteria Mycobacterium Tuberculosis (TBC). Most of the TB germs attack the lungs, but can also affect other organs (Kementerian Kesehatan RI, 2014). Until now, pulmonary TB is still a global public health problem and a world concern. In 2014 pulmonary TB killed 1.5 million, consisting of 890,000 men, 480,000 women and 140,000 children.

In 2016 the incidence of pulmonary tuberculosis has increased very rapidly by 10.4 million or 140 cases per 100,000 population, where the total population with age under or equal to 14 years is 1.05 million cases while the population over 14 years is 9,36 million cases. Compared to 2014 there were 9.6 million cases of pulmonary TB but only 6 million cases were reported, meaning that there were 3.6 million cases that were undiagnosed or unreported.
Meanwhile, globally there are 1.3 million deaths and 374,000 deaths due to tuberculosis with HIV per year. India, Indonesia and China are the countries with the highest number of new tuberculosis cases, namely 2.8 million 1.2 million and 979 thousand cases, respectively, from all new cases in the world throughout 2016.

In 2015, it was found that the number of tuberculosis cases was 330,910 cases, an increase compared to all tuberculosis cases found in 2014 which amounted to 324,539 cases. The highest number of cases reported was in West Java, East Java and Central Java Provinces. Tuberculosis cases in these three provinces account for 38 percent of the total number of new cases in Indonesia. North Sumatra Province is fourth after Central Java province (Kementerian Kesehatan RI, 2016).

Based on data from the Health Profile of North Sumatra Province, the discovery of pulmonary tuberculosis cases in 2014 was in 
accordance with the Case Notification Rate (CNR) figure of 122 per 100,000 population, while in 2016 it was 105 per 100,000 population and in 2017 the discovery of new cases of pulmonary TB in North Sumatra was 104 per 100,000 population, has decreased compared to 2014. For Medan City, the number of pulmonary TB cases was 2,829 cases in 2016. This figure has decreased compared to 2015 of 3,111 cases, where we can see the Case Notification Rate (NCR) figure in 2015 amounted to 294 per 100,000 population and in 2016 amounted to 287 per 100,000 population.

The main causes of the increasing problem of pulmonary tuberculosis include poverty in various groups of society, high economic growth but with too wide disparities and the burden of social determinants such as unemployment, low education levels, low per capita income which results in Community vulnerability to nutritional status which leads to pulmonary $\mathrm{TB}$ incidence (Kementerian Kesehatan RI, 2014).

Based on the medical record data of the UPT Specialized Pulmonary Hospital in 2014 to 2016 , it can be seen that in 2014 the number of pulmonary TB patients was 237 patients, where the number of patients with a history of household contact was 71 patients or $29.95 \%$. In 2015 the number of pulmonary TB patients was 214 patients, a history of household contacts was 66 patients or $30.84 \%$, and in 2016 the number of pulmonary TB patients was 315 patients with a history of household contacts as many as 98 patients or $31,11 \%$.

The results of the initial survey conducted at the Specialized Hospital for Pulmonary of 15 patients with pulmonary TB indicated that 13 patients said they had household contact with pulmonary TB patients. A total of 11 patients said that their income was below Rp. 2.7 million / month and the nutritional status is also not good. The observations made also show that the occupancy of the house that is occupied does not meet the health requirements.

Based on this description, by looking at the phenomenon of the high incidence of pulmonary tuberculosis due to household contact at the UPT of the Special Hospital for Pulmonary, Health Service of North Sumatra Province, Medan, researchers are interested in conducting research on "The Effect of Nutrition Status And Dwelling Density Compliance With Home Contact Pulmonary Tb Insidence In Specialized Hospital Of Pulmonary 2018".

\section{Methods}

This type of research is an observational study with a case control study design. This research was conducted at UPT. Specialized Pulmonary Hospital in the Health Office of North Sumatra Province, Medan. The case population was all patients who were diagnosed with pulmonary $\mathrm{TB}$ and confirmed smear positive and there was a history of home contact with pulmonary TB patients who were treated at the UPT. Medan Pulmonary Hospital. The control population was all patients who were declared not suffering from TB and confirmed negative smear and there was a history of home contact with pulmonary $\mathrm{TB}$ patients who were treated at the UPT.

The sample in this study consisted of case samples and control samples aged 1564 years who were treated at the UPT. The Specialized Pulmonary Hospital in Medan were 60 (cases) and 60 (controls) where samples were taken by consecutive sampling. Data were collected through observation and interviews using a questionnaire. Bivariate analysis was performed using simple logistic regression test and multivariate analysis using multiple logistic regressions.

\section{Result and Discussion}

The results of this study were described in univariate, bivariate, and multivariate ways. The following is a deeper explanation of the data analysis methods used in this study:

Univariate analysis aims to determine the percentage of each frequency distribution, namely nutritional status and occupancy density. Table 1 explains that most of the respondents in the case and control groups have low nutritional status. The occupancy density in the majority of cases was dense, while in the control group, it was not dense.

The bivariate analysis used to determine the effect of nutritional status and occupancy density on the incidence of pulmonary tuberculosis in household contacts is by using the Simple Logistic Regression test. Table 2 shows that there is an effect of nutritional status and occupancy density on the incidence 
of household contact pulmonary $\mathrm{TB}$ at the UPT. Specialized Pulmonary Hospital Medan. Table 3. Shows that nutritional status is the most influential variable in the incidence of household contact pulmonary TB at the UPT. Specialized Pulmonary Hospital in Medan with an OR value of 2.775 times (95\% CI 1.2546.139).

The Effect of Nutritional Status on Incidence of Household Contact Pulmonary TB

The results of this study indicate that there is an influence on nutritional status against the incident Pulmonary TB in-house contact at a Specialized Pulmonary Hospital in Medan, where $p=0.009$. The results of this study also showed that most of the respondents in the case group had a malnutrition status, namely $75 \%$. The state of poor nutritional status is closely related to pulmonary TB infection. A person who has decreased nutrition will have a low immune system and is very susceptible to disease so that the immune response to infectious diseases decreases (Kementerian Kesehatan RI, 2011). There was a relationship between nutritional status and the incidence of pulmonary TB in North Sulawesi Province.

Table 1. Frequency Distribution of Respondents based on Nutritional Status and Occupancy Density

\begin{tabular}{lllll}
\hline \multirow{2}{*}{ Variable } & \multicolumn{2}{c}{ Cases } & Control \\
\cline { 2 - 5 } & $\mathrm{n}$ & $\%$ & $\mathrm{n}$ & $\%$ \\
\hline Nutritional status & 45 & 75 & 31 & 51.7 \\
Risky & 15 & 25 & 29 & 48.3 \\
Not risky & & & & \\
Occupancy Density & 41 & 68.3 & 27 & 45 \\
Densely populated areas & 19 & 31.7 & 33 & 55 \\
Undensely populated areas & & &
\end{tabular}

Source: Primary data 2018

Table 2. Effect of Nutritional Status and Occupancy Density on Incidence of Household Contacts Pulmonary TB

\begin{tabular}{|c|c|c|c|c|c|c|c|c|}
\hline \multirow{3}{*}{\multicolumn{2}{|c|}{ Variable }} & \multicolumn{4}{|c|}{ Pulmonary TB incidence } & \multirow{3}{*}{$\mathrm{p}$} & \multirow{3}{*}{ OR } & \multirow{3}{*}{$95 \% \mathrm{CI}$} \\
\hline & & \multicolumn{2}{|c|}{ Cases } & \multicolumn{2}{|c|}{ Control } & & & \\
\hline & & $\mathrm{n}$ & $\%$ & $\mathrm{n}$ & $\%$ & & & \\
\hline \multicolumn{9}{|c|}{ Nutritional status } \\
\hline \multicolumn{2}{|c|}{ Risky } & 45 & 75 & 31 & 51.7 & 0,009 & 2,806 & $1,295-6,081$ \\
\hline \multicolumn{2}{|c|}{ Unrisky } & 15 & 25 & 29 & 48.3 & & & \\
\hline \multicolumn{9}{|c|}{ Occupancy Density } \\
\hline \multicolumn{2}{|c|}{ Densely populated areas } & 41 & 68.3 & 27 & 45 & 0,011 & 2,637 & $1,252-5,554$ \\
\hline \multirow{2}{*}{\multicolumn{2}{|c|}{$\begin{array}{l}\text { Undensely populated areas } \\
\text { Source: Primary data } 2018\end{array}$}} & 19 & 31.7 & 33 & 55 & & & \\
\hline & & & & & & & & \\
\hline \multirow{2}{*}{\multicolumn{2}{|c|}{ No. Variable }} & 1011 & \multirow{2}{*}{ B } & \multirow{2}{*}{\multicolumn{2}{|c|}{$\mathrm{p}$}} & \multirow{2}{*}{ OR } & \multicolumn{2}{|c|}{$95 \% \mathrm{CI}$} \\
\hline & & & & & & & Lower & Upper \\
\hline 1. & Nutritional status & & 1.021 & 0.01 & & 2.775 & 1.254 & 6.139 \\
\hline 2. & Occupancy density & & 0.959 & 0.01 & & 2.608 & 1.212 & 5.612 \\
\hline 3. & Constant & & -1.198 & 0.00 & & & & \\
\hline
\end{tabular}

Source: Primary data 2018 
Malnutrition can increase the development of active TB and active TB causes malnutrition to get worse.

The prevalence of malnutrition in pulmonary TB patients is quite high, especially in developing countries, including Indonesia. A high proportion ofTB patients aremalnourished. TB patients are very vulnerable to malnutrition and even the very distal reasons for malnutrition in society are proximal causes for TB patients (Feleke et al., 2019). Shukla et al. (2019) stated the proportion of severe malnutrition among pulmonary TB patients. There is an urgent need for the provision of appropriate nutritional management and hospital counseling of $\mathrm{TB}$ in hospitals according to national nutrition guidelines for TB patients. Poor nutrition in pulmonary tuberculosis patients can be caused by anorexia, impaired nutrient absorption, or increased body catabolism. Malnutrition in pulmonary tuberculosis patients if not identified immediately will cause more serious health problems, such as an increase in mortality (Dargie et al., 2016).

The relationship between $\mathrm{TB}$ and malnutrition is two-way, TB makes patients malnourished and malnutrition increases the risk of developing active TB by 6 to 10 times (Bhargava et al., 2014). The World Health Organization (2013) stated that a quarter of $\mathrm{TB}$ in the world is a result of malnutrition improving individual nutritional status reduces the risk of TB.

Tuberculosis can reduce energy intake caused by changes in metabolism due to decreased appetite as part of the inflammatory response and immunity (Mehta, 2016). A study in Uganda found that there was a decrease in a number of nutrients, consisting of macronutrients and micronutrients, such as carbohydrates, energy, protein, total fat, calcium, vitamin $\mathrm{A}$, and folate in pulmonary TB patients (Mupere et al., 2012). The high incidence of malnutrition can be caused by several things such as bad food habits, ignorance of nutritious and balanced food intake, and low educational background (Chatterjee et al., 2015).

(Oktavia et al., 2016) stated that the proportion of the nutritional status of respondents who were underweight (body weight less than BMI) in the case group was
$81.8 \%$ while in the control group it was $21.2 \%$. The proportion in the case group was almost four times that of the control group with an OR value of 16.7 (95\% CI 4.95 -56.39). People with poor nutritional status have an increased risk of developing pulmonary TB 16.7 times than respondents with normal / excess nutritional status. There was a statistically significant relationship between nutritional status and the incidence of pulmonary tuberculosis ( $\mathrm{p}$-value 0.001 ).

The state of poor nutritional status is closely related to pulmonary TB disease. Decreased nutrition or malnutrition will have low body resistance and are very susceptible to disease so that the immune reaction against infectious diseases decreases. Increasing the social economy level and increasing body resistance by eating a balanced nutritional diet can improve a person's nutritional status so as to avoid pulmonary TB disease (Kementerian Kesehatan RI, 2011).

Research conducted by Nurwitasari and Wahyuni (2015) concluded that contact history, length of contact, and closeness influenced the incidence of child tuberculosis in Jember Regency. It is necessary to actively search for new cases to break the chain of transmission of tuberculosis infection with in-house contact checks as early as possible.

The Effect of Occupancy Density on the Incidence of in-House Contact of Pulmonary $\mathrm{TB}$

The environment is one of the risk factors that influence the incidence of pulmonary TB, especially in densely populated areas. This study explains that there is an effect of occupancy density on the incidence of pulmonary $\mathrm{TB}$ in household contacts who seek treatment at the Specialized Hospital for Pulmonary in Medan. Based on the results of this study, the occupancy density variable in the case sample mostly had a density of occupancy that did not meet the requirements or was dense, namely $68.3 \%$ and the control was $45 \%$, which met the requirements or was not crowded in the case sample by $31.7 \%$ while the control was equal to $55 \%$. The results of the simple logistic regression analysis showed $\mathrm{p}$ value $=0.011$, the results of multivariate analysis using the enter method obtained OR $=2.645 ; 95 \% \mathrm{CI}$ 
1,031-6,788 means that the variable occupancy density has a significant effect on the incidence of household contact pulmonary TB.

This is in line with the research of Wulandari et al. (2015) explained that there was a relationship between occupancy density and the incidence of pulmonary TB in Kendal Regency, Central Java with a p value of 0.001 . Mawardi and Indah (2014) also stated that there was a relationship between occupancy density and pulmonary TB disease in Kapuas District. Research conducted by Hill et al. (2006) in The Gambia show that household overcrowding and previous household exposure to known $\mathrm{TB}$ cases are prominent risk factors for $\mathrm{TB}$ disease. Prihanti and Rahmawati (2017) also mentioned a relationship between occupancy density and the incidence of pulmonary TB. The results showed that in the case group there were 23 people (69.7\%) with a density of residents who did not meet the requirements, while in the control group there were 30 people (90.9\%) with a density of residents who met the requirements.

The physical conditions of the home environment that are related to the incidence of pulmonary tuberculosis are occupancy density, natural ventilation and natural lighting, both in the dominant room and the respondent's bedroom (Deny, 2014). Occupant density is a risk factor for pulmonary TB. The denser the house, the easier and faster transfer of disease through the air, if there is a family member suffering from TB with positive AFB who accidentally coughs. Pulmonary TB bacteria will stay in the air for approximately 2 hours so that they have the possibility to transmit the disease to members who have not been exposed to these bacteria. The results of this study are consistent with research in India that a contaminated household environment increases the risk of Tuberculosis in India (Singh et al., 2018).

The results of this study are in line with research conducted by Anggraeni and Rahayu (2018) showing that occupancy density ( $\mathrm{p}=$ $0.007)$, ventilation ( $p=0.003$ ), and nutritional status $(\mathrm{p}=0.030)$ are associated with clinical symptoms of tuberculosis in families with tuberculosis AFB positive. The conclusion of this study is that there is a relationship between occupancy density, ventilation, and nutritional status with clinical symptoms of tuberculosis. The residence of most of the pulmonary TB sufferers has not met the criteria for a healthy home in terms of occupancy density, lighting, ventilation, and humidity (Suharyo, 2013).

The case group that has a densely populated house must make good use of air ventilation in the form of the habit of opening windows every day, especially in the morning, having separate eating or drinking utensils for TB sufferers and not throwing phlegm in random places to prevent pulmonary $\mathrm{TB}$ transmission to other family members. A healthy home must have good ventilation because as a function of keeping the air flow fresh, freeing room air from bacteria, and keeping the room in optimum humidity.

A house with an unhealthy condition or not meeting health requirements can be a medium for transmitting respiratory diseases, one of which is pulmonary tuberculosis. This disease can be exacerbated by poor housing sanitation conditions, especially in dense settlements and poor people. Research conducted by Aditama et al. (2019) showed that occupancy density and ventilation were the biggest risk factors for pulmonary tuberculosis in the Lhoong $\mathrm{CHC}$ Aceh Besar district in 2018. Muslimah (2019) concluded that there was a relationship between temperature, humidity and lighting with the presence of Mycobacterium tuberculosis in the room air get together.

Occupancy density is also closely related to a person's socio-economic factors, because a small income makes people unable to live properly that meets health requirements. Dye et al. (2009) argued that TB transmission and development was largely driven by social factors such as poor living conditions and malnutrition. Standards for public housing are basically aimed at providing adequate housing in the form of design, location and size of the room, as well as other facilities in order to meet family needs or to fulfill the requirements of a healthy and pleasant home. A bad house or place of residence or slum can support the transmission of diseases and health problems such as pulmonary TB. Muchsin et al. (2019) argued that to break the chain of pulmonary TB 
transmission, it is necessary to increase public awareness about the importance of healthy living habits and a healthy home by providing health education about the requirements for good nutritional status and ventilation.

The results of the study (Rohayu et al., 2017) shown that there is a relationship between occupancy density and the incidence of pulmonary $\mathrm{TB}$. These results indicate that the size of the room in a house is closely related to the incidence of pulmonary tuberculosis. The largest incidence of pulmonary tuberculosis is caused by conditions in the house that do not meet the requirements for the size of the room. The results of this study indicate that the proportion of respondents whose occupancy density does not meet the requirements is more, namely 21 respondents (52.5\%) compared to respondents whose occupancy density meets the requirements of 19 respondents (47.5\%). The occupancy density that did not meet the requirements but did not suffer from positive smear pulmonary $\mathrm{TB}$ in the control group there were several respondents, this was due to a low economic situation so that there were still many respondents consisting of 2 heads of families (KK) living in one house with no density conditions meet the requirements of $<9$ $\mathrm{m}^{2} /$ person, based on information obtained by researchers in the field that this is also supported by the habit of respondents opening windows in the morning besides that some respondents also live a healthy lifestyle and have a history of low-risk contacts, while in the case group there are several respondents who have occupancy densities that meet the requirements but suffer from smear positive pulmonary TB, this is due to a lack of understanding of the transmission of pulmonary TB disease. Contact history and occupancy density are risk factors for pulmonary TB.

The results of research by Oktavia et al. (2016) also obtained an OR value of 4.3 (95\% CI 1.38-12.94), indicating that homes with high occupancy densities have a 4.3 times risk of experiencing pulmonary TB incidence compared to densely populated homes. A house with a high occupancy density increases the risk of getting pulmonary TB by 1.38 to 12.94 times compared to a less dense occupancy. In conclusion, with a p-value of $0.016<\alpha 0.05$, it means that there is a statistically significant relationship between occupancy density and the incidence of pulmonary tuberculosis. This research is supported by the results of research conducted by Fitriani (2013) showing the results of the chi-square analysis, obtained a p value of 0.000 and an OR value of 5.4 (95\% CI 1.88515.637), meaning that there is a relationship between environmental conditions and the incidence of pulmonary tuberculosis and poor environmental conditions have a 5.4 times risk of increasing the incidence of pulmonary TB.

\section{Conclusion}

There is an effect of nutritional status on the incidence of contact pulmonary TB in a specialized pulmonary hospital in Medan and the state of malnutrition status is closely related to pulmonary TB infection. Environmental factors are one of the risk factors that influence the incidence of pulmonary $\mathrm{TB}$, especially in densely populated areas. Occupancy density is also related to a person's socio-economic factors, because a small income makes people unable to live properly and meet health requirements.

\section{References}

Aditama, W., Sitepu, F.Y., \& Saputra, R., 2019. Relationship between Physical Condition of House Environment and the Incidence of Pulmonary Tuberculosis, Aceh, Indonesia. International Journal of Science and Health Care Research, 4(1),pp.227-231.

Anggraeni, D.E., \& Rahayu, S.R., 2018. Gejala Klinis Tuberkulosis pada Keluarga Penderita Tuberkulosis BTA Positif. HIGEIA (Journal of Public Health Research and Development), 2(1),pp.91-101.

Bhargava, A., Oxlade, O., \& Pai, M.D., 2014. Undernutrition and the Incidence of Tuberculosis in India: National and Subnational Estimates of the Population Attributable Fraction Related to Undernutrition. National Medical Journal of India, 27(3),pp.128-33.

Chatterjee, K., Ray, S., Das, B., Bhuniya, D.K., \& Dash, S.S., 2015. Study of the Nutritional Status of High School Students from Medinipur Sadar Subdivision, Paschim Medinipur District, West Bengal, India. The International Journal of Science and Technoledge, 3(5),pp.137.

Dargie, B., Tesfaye, G., \& Worku, A., 2016. Prevalence and Associated Factors of Undernutrition Among Adult Tuberculosis Patients in Some Selected Public Health Facilities of Addis 
Ababa, Ethiopia: A Cross-sectional Study. BMC Nutrition, 2(1),pp.7.

Deny, A., 2014. Hubungan Kondisi Fisik Lingkungan Rumah dengan Kejadian Tuberkulosis Paru di Wilayah Kerja Puskesmas Perumnas i dan II Kecamatan Pontianak Barat. Jurnal Mahasiswa PSPD FK Universitas Tanjungpura, 1(1).

Dye, C., Lönnroth, K., Jaramillo, E., Williams, B., \& Raviglione, M., 2009., Trends in Tuberculosis Incidence and Their Determinants in 134 Countries. Bulletin of the World Health Organization, 2009, 87683-691.

Feleke, B.E., Feleke, T.E., \& Biadglegne, F., 2019. Nutritional Status of Tuberculosis Patients, A Comparative Cross-sectional Study. BMC Pulmonary Medicine, 19(1):pp.182.

Fitriani, E., 2013. Faktor Risiko Yang Berhubungan Dengan Kejadian Tuberkulosis Paru (Studi Kasus di Puskesmas Ketanggungan Kabupaten Brebes Tahun 2012). Unnes Journal of Public Health, 2(1).

Hill, P.C., Jackson-Sillah, D., Donkor, S.A., Otu, J., Adegbola, R.A., \& Lienhardt, C., 2006. Risk Factors for Pulmonary Tuberculosis: A Clinic-based Case Control Study in The Gambia. BMC Public Health, 6(1),pp.156.

Kemenkes, RI., 2011. Strategi Nasional Pengendalian TB di Indonesia 2010-2014. Jakarta: Direktorat Jenderal Pengendalian Penyakit dan Penyehatan Lingkungan Kementrian Kesehatan RI.

Kemenkes RI., 2014. Pedoman Nasional Pengendalian Tuberkulosis. Direktorat Jenderal Pengendalian Penyakit dan Penyehatan Lingkungan, Kementerian Kesehatan Republik Indonesia

Kemenkes RI., 2016. Profil Kesehatan Indonesia Tahun 2015. Jakarta: Pusat Data dan Informasi Kementerian Kesehatan RI.

Mawardi., \& Indah, M.F., 2014. Hubungan Kondisi Fisik Rumah dan Kepadatan Hunian dengan Kejadian TB Paru Di Wilayah Kerja Upt Puskesmas Dadahup Kecamatan Dadahup Kabupaten Kapuas. An-Nadaa: Jurnal Kesehatan Masyarakat, 1(1),pp.14-20.

Mehta, M., 2016. Impact of Nutrition Education on Pulmonary Tuberculosis Patients. Global Journal for Research Analysis, 5(6),pp.317320.

Muchsin, M., Siregar, F.A., \& Sudaryati, E., 2019. The Influence of Nutritional Status and Ventilation on the Incidence of Pulmonary Tuberculosis at Langsa. Open Access
Macedonian Journal of Medical Sciences, $7(20)$.

Mupere, E., Parraga, I.M., Tisch, D.J., Mayanja, H. K., \& Whalen, C.C., 2012. Low Nutrient Intake Among Adult Women and Patients with Severe Tuberculosis Disease in Uganda: A Cross-sectional Study. BMC Public Health, 12(1),pp.1050.

Muslimah, D., 2019. Keadaan Lingkungan Fisik Dan Dampaknya Pada Keberadaan Mycobacterium Tuberculosis: Studi Di Wilayah Kerja Puskesmas Perak Timur Surabaya. Jurnal Kesehatan Lingkungan, 11(1),pp.26.

Nurwitasari, A., \& Wahyuni, C.U., 2015. Pengaruh Status Gizi dan Riwayat Kontak Terhadap Kejadian Tuberkulosis Anak di Kabupaten Jember. Jurnal Berkala Epidemiologi, 3(2),pp.158-169.

Oktavia, S., Mutahar, R., \& Destriatania, S., 2016. Analisis Faktor Risiko Kejadian TB Paru di Wilayah Kerja Puskesmas Kertapati Palembang. Jurnal Ilmu Kesehatan Masyarakat, 7(2).

Prihanti, G.S. \& Rahmawati, I., 2017., Analisis Faktor Risiko Kejadian Tuberkulosis Paru. Saintika Medika: Jurnal Ilmu Kesehatan dan Kedokteran Keluarga, 11(2),pp.127-132.

Rohayu, N., Yusran, S., \& Ibrahim, K., 2017. Analisis Faktor Risiko Kejadian TB Paru BTA Positif pada Masyarakat Pesisir di Wilayah Kerja Puskesmas Kadatua Kabupaten Buton Selatan Tahun 2016. Jurnal Ilmiah Mahasiswa Kesehatan Masyarakat, 1(3).

Shukla, A., Pandey, S., Singh, S., \& Sharma, J., 2019. Nutritional Status of Pulmonary Tuberculosis Patients: A Hospital-based Cross-sectional Study. Indian Journal of Community and Family Medicine, 5(2),pp.134.

Singh, S., Kashyap, G.C., \& Puri, P., 2018. Potential Effect of Household Environment on Prevalence of Tuberculosis in India: Evidence from the Recent Round of a Crosssectional Survey. BMC pulmonary medicine, 18(1),pp.66.

Suharyo., 2013. Determinasi Penyakit Tuberkulosis di Daerah Pedesaan. KEMAS: Jurnal Kesehatan Masyarakat, 9(1),pp.85-91.

Wulandari, A.A., Nurjazuli, N., \& Adi, M.S., 2015. Faktor Risiko dan Potensi Penularan Tuberkulosis Paru di Kabupaten Kendal, Jawa Tengah. Jurnal Kesehatan Lingkungan Indonesia, 14(1),pp.7-13. 